\title{
Tingkat pendapatan dan pola makan berhubungan dengan status gizi balita di Daerah Nelayan Distrik Jayapura Utara Kota Jayapura
}

\author{
Income level and diet pattern had correlation with nutritional status of underfive in fisherman area \\ of North Jayapura District Jayapura Municipality
}

Vonny Persulessy¹, Abidillah Mursyid², Agus Wijanarka²

\begin{abstract}
Background: Nutrition has an important role in human life cycle. Undernourishment in infants and underfives can cause growth and development disorder. Development of Papua community begins from village empowerment, such as nutrition improvement, health service, and people's economy. There are 544 fisherman families at District of Jayapura Utara. Main stipend of Papua community consists of rice, sago, hipere, taro and banana. Sago is consumed by the majority of people residing at coastal areas. Nutrition Status Monitoring of Jayapura Municipal Health Office in 2008 indicated that $3.4 \%$ of underfives were malnourished, $17.8 \%$ undernourished, $76 \%$ well nourished and $2.8 \%$ overnourished.

Objectives: To identify correlation between level of income and diet pattern with nutritional status of underfive in fisherman area of Jayapura District Jayapura Municipality.

Methods: The study was observational with cross sectional design. The independent variables were level of income and eating pattern; the dependent variable was nutritional status. The study was undertaken in October-December 2010 at District of North Jayapura, Jayapura Municipality involving 162 underfives (of 12-59 moths), and mothers of underfives as respondents. Data were obtained through questionnaire of income, eating pattern using food frequency questionnaire, nutritional status measured from anthropometry based on weight/age standard of WHO 2005. Data analysis used bivariate with chi square, multivariate with multiple logistic regression.

Results: There was significant correlation between income level with nutritional status with $(p=0.000)$ and between diet pattern with nutritional status $(p=0.000)$.

Conclusions: Underfives having parents with sufficient income had better nutritional status than those having parent with insufficient income. Underfives with good diet pattern had better nutritional status than those with poor diet pattern.
\end{abstract}

KEYWORDS: income, diet pattern, nutrition status of underfives, fisherman area

\begin{abstract}
ABSTRAK
Latar belakang: Secara nasional, prevalensi balita gizi buruk dan kurang menurun sebanyak 0,5\% menjadi 17,9\%. Prevalensi gizi buruk dan kurang Provinsi Papua menurut Riskesdas tahun 2010 sebanyak 16,3\%. Data neraca bahan makanan (NBM) Provinsi Papua secara kuantitas menunjukkan rata-rata peningkatan produksi bahan makanan di antaranya beras, jagung, umbi-umbian. Secara kualitas, energi dan protein melebihi angka kecukupan gizi (AKG), tetapi status gizi buruk dan kurang di Kota Jayapura mencapai $21,2 \%$ yang dipengaruhi oleh banyak faktor, yaitu tingkat pendapatan, pola makan, pengetahuan ibu, jumlah anggota dalam keluarga.

Tujuan: Untuk mengetahui hubungan antara tingkat pendapatan dan pola makan dengan status gizi balita di daerah nelayan Distrik Jayapura Utara, Kota Jayapura.
\end{abstract}

\footnotetext{
${ }^{1}$ Puskesmas Imbi, Kel. Imbi Dok VIII, Distrik Jayapura Utara, e-mail: vonnypersulessy@gmail.com

${ }^{2}$ Politeknik Kesehatan Kementerian Kesehatan Yogyakarta, JL.Tata Bumi, Yogyakarta
} 
Metode: Penelitian ini merupakan penelitian observasional dengan rancangan cross sectional. Jumlah sampel sebanyak 162 balita (usia 12-59 bulan) dan ibu balita sebagai responden. Pengumpulan data menggunakan kuesioner tingkat pendapatan, pola makan anak dalam keluarga menggunakan food frequency questionnaire (FFQ), status gizi diukur menggunakan antropometri berdasarkan BB/U standar baku WHO 2005. Analisis data bivariat menggunakan chi-square, sedangkan analisis multivariat menggunakan multiple logistic regression.

Hasil: Tingkat pendapatan dengan status gizi menunjukkan hubungan yang bermakna dengan nilai $(p=0,000)$. Pola makan dengan status gizi menunjukkan hubungan yang bemakna yaitu $(p=0,010)$. Variabel luar pengetahuan ibu dengan status gizi, jumlah anggota keluarga dengan status gizi tidak menunjukkan hubungan yang bermakna, yaitu $p>0,05$.

Kesimpulan: Terdapat hubungan yang bermakna antara tingkat pendapatan dengan status gizi, pola makan dengan status gizi. Tetapi tidak ditemukan hubungan yang bermakna antara pengetahuan ibu dengan status gizi, dan jumlah anggota keluarga dengan status gizi.

KATA KUNCI: tingkat pendapatan, pola makan, status gizi balita, daerah nelayan

\section{PENDAHULUAN}

Usia 0-24 bulan merupakan masa pertumbuhan dan perkembangan yang pesat yang sering disebut dengan periode emas sekaligus periode kritis. Pada periode ini, jika bayi dan anak balita memperoleh pola makan dan asupan gizi yang baik sesuai tumbuh kembang optimal, maka periode emas ini dapat terwujud. Sebaliknya, jika pada periode ini bayi dan anak balita tidak memperoleh asupan gizi yang cukup sesuai kebutuhannya, maka periode emas akan menjadi periode kritis yang dapat menyebabkan tumbuh kembang bayi dan anak balita akan berjalan sebagaimana mestinya. Gizi memegang peranan penting dalam siklus hidup manusia. Kekurangan gizi pada bayi dan anak balita akan mengakibatkan gangguan pertumbuhan dan perkembangan (1).

Secara nasional, prevalensi balita gizi buruk dan kurang menurun sebanyak $0,5 \%$ yaitu dari $18,4 \%$ pada tahun 2007 menjadi $17,9 \%$ pada tahun 2010. Provinsi Papua berdasarkan data Riskesdas tahun 2010 untuk berat badan menurut umur (BB/U) diketahui prevalensi gizi buruk sebesar 6,3\% dan gizi kurang sebesar 10\%. Dengan demikian, prevalensi gizi kurang dan buruk sebanyak 16,3\% (2), sedangkan data pemantauan status gizi (PSG) Dinas Kesehatan Kota Jayapura tahun 2008 diketahui terdapat $3,4 \%$ balita gizi buruk, $17,8 \%$ gizi kurang, $76 \%$ gizi baik, dan 2,8\% gizi lebih (3). Peta balita gizi kurang dan gizi buruk sebagian besar berada di daerah pinggiran pantai.
Masyarakat Papua mengonsumsi makanan pokok beras dan makanan pokok non beras yang merupakan bahan makanan lokal yang terdiri dari sagu, hipere atau ubi jalar, dan talas. Sagu dikonsumsi oleh sebagian masyarakat yang tinggal di pesisir pantai, hipere, dan talas dikonsumsi oleh sebagian masyarakat yang tinggal di pegunungan (4).

Sumber penghasilan rumah tangga nelayan di Distrik Jayapura Utara berasal dari perikanan laut dengan jumlah 535 dan perikanan darat sebanyak 9 rumah tangga (5). Masyarakat nelayan menempati rumah tinggal yang terbuat dari kayu dan berada di atas laut (rumah berlabuh) dengan ventilasi dan pencahayaan yang sebagian belum memenuhi syarat rumah sehat.

Komunitas yang mendominasi pekerjaan sebagai nelayan di daerah pesisir pantai yaitu masyarakat Serui dan Jayapura dari Kampung Kayo Batu (asli Papua), Bugis/Makassar dan Buton (non asli/pendatang). Masyarakat nelayan memperoleh tambahan penghasilan yang diperoleh dari berjualan pinang dan sirih, sagu dan umbi-umbian, ikan segar, ikan asap, dan hasil laut lainnya, serta sayuran dan buah. Rata-rata distribusi tingkat pendapatan per kapita keluarga nelayan sebesar Rp 407.700,-.

Harga pangan dan daya beli keluarga terkait dengan tingkat pendapatan keluarga, ketersediaan pangan di daerah setempat, serta pengetahuan ibu tentang gizi dan kesehatan dalam pemilihan bahan makanan yang berkualitas bagi keluarga. Taraf 
sosio-ekonomi dan adat kebiasaan setempat serta jumlah anggota keluarga yang banyak dalam satu rumah memegang peranan penting dalam pola konsumsi penduduk.

Melihat kondisi yang ada di lapangan, pemberdayaan yang dilakukan oleh pemerintah saat ini adalah dengan program Respek (Rencana Strategis Pembangunan Kampung). Pembangunan masyarakat Papua dimulai dari pembangunan kampong dengan peningkatan kapasitas pemerintahan kampung dan distrik. Fokus program adalah perbaikan gizi, pelayanan kesehatan, pendidikan, perumahan, ekonomi kerakyatan, dan infrastruktur kampung (6). Oleh karena itu, perlu dilakukan penelitian tentang hubungan tingkat pendapatan, pola makan, pengetahuan ibu, dan jumlah anggota keluarga dengan status gizi balita di daerah nelayan Distrik Jayapura Utara, Kota Jayapura. Tujuan penelitian ini untuk mengetahui distribusi tingkat pendapatan dan pola makan, gambaran status gizi balita, hubungan tingkat pendapatan dengan status gizi balita, dan hubungan pola makan dengan status gizi balita.

\section{BAHAN DAN METODE}

Penelitian ini merupakan penelitian cross sectional (7). Lokasi penelitian di Distrik Jayapura Utara, Kota Jayapura pada periode Oktober-Desember 2010. Populasi adalah balita berusia $12-59$ bulan. Besar sampel dihitung menggunakan rumus estimasi perbedaan dua proporsi (8). Jumlah sampel sebesar 162 balita yang dipilih secara systematic random sampling. Variabel terikat adalah status gizi, variabel bebas adalah tingkat pendapatan dan pola makan, sedangkan variabel luar yaitu pengetahuan ibu tentang gizi dan jumlah anggota keluarga.

Data penelitian diambil dengan bantuan 6 enumerator berpendidikan minimal DIII Gizi yang telah mendapat pengarahan dan pelatihan untuk menyamakan persepsi. Penelitian dilakukan dengan pengambilan data primer menggunakan kuesioner. Data tingkat pendapatan menggunakan kuesioner pengeluaran rumah tangga yang sudah divalidasi, data pola makan menggunakan food frequencyquestionnaire (FFQ) yang dimodifikasi menurut bahasa dan jenis makanan khas daerah, data pengetahuan ibu tentang gizi dan jumlah anggota keluarga menggunakan kuesioner yang telah divalidasi, sedangkan data status gizi diperoleh dengan mengukur berat badan menurut umur (BB/U) yang dibandingkan dengan standar WHO 2005. Pengolahan data status gizi dilakukan menggunakan software WHO 2005. Data karakteristik dikumpulkan melalui kuesioner dan data demografi diperoleh dari badan pusat statistik (BPS) Provinsi Papua dan BPS Kota Jayapura.

Analisis data dilakukan secara bertahap melalui analisis univariat, bivariat menggunakan chi-square, dan multivariat menggunakan uji multiple logistic regression. Pengolahan dan analisis data diawali dengan editing, coding, dan cleaning, kemudian uji statistik menggunakan program software statistic. Penelitian dilaksanakan setelah mendapat ethical clereance dari Komite Etik Fakultas Kedokteran Universitas Gadjah Mada dengan nomor: KE/FK/624/ EC tahun 2010, setelah mendapat persetujuan dan kesediaan menjadi responden dengan mengisi dan menandatangani informed consent.

\section{HASIL}

\section{Karakteristik dasar penelitian}

Subjek dalam penelitian ini berjumlah 162 balita yang berumur 12-59 bulan. Karakteristik subjek meliputi jenis kelamin dan umur balita. Karakteristik responden meliputi umur ibu, pendidikan, dan pekerjaan.

Berdasarkan Tabel 1 kategori umur, jumlah balita yang sudah mengikuti pola makan keluarga berada pada umur 12-36 bulan dan memiliki status gizi kurang berjumlah 40 anak $(64,5 \%)$. Ibu balita yang berumur $\leq 35$ tahun dan termasuk kategori gizi kurang berjumlah 56 orang (90,3\%). Pendidikan ibu pada pendidikan dasar dan memiliki balita berstatus gizi kurang, yaitu sebanyak 33 orang $(53,2 \%)$.

Pada penelitian ini, orang tua balita yang mempunyai tingkat pendapatan kurang sebanyak 51 orang $(31,5 \%)$ Terdapat pola makan kurang (jenis dan frekuensi $<3$ kali sehari) sebanyak 76 orang $(46,9 \%)$ Balita yang mempunyai status gizi kurang berjumlah 62 anak (38,3\%). 
Tabel 1. Karakteristik dasar penelitian yang dikaji berdasarkan status gizi

\begin{tabular}{|c|c|c|c|c|c|c|}
\hline \multirow{3}{*}{ Variabel } & \multicolumn{4}{|c|}{ Status gizi } & \multirow{3}{*}{$c^{2}$} & \multirow{3}{*}{$\mathbf{p}$} \\
\hline & \multicolumn{2}{|c|}{ Kurang } & \multicolumn{2}{|c|}{ Baik } & & \\
\hline & $\mathbf{n}$ & $\%$ & $\mathbf{n}$ & $\%$ & & \\
\hline \multicolumn{7}{|l|}{ Jenis kelamin balita } \\
\hline Laki-laki & 29 & 46,8 & 55 & 55,0 & 1,03 & 0,308 \\
\hline Perempuan & 33 & 53,2 & 45 & 45,0 & & \\
\hline \multicolumn{7}{|l|}{ Umur balita (bulan) } \\
\hline $12-36$ & 40 & 64,5 & 72 & 72,0 & 1,00 & 0,316 \\
\hline $37-59$ & 22 & 35,5 & 28 & 28,0 & & \\
\hline \multicolumn{7}{|l|}{ Umur ibu (tahun) } \\
\hline$\leq 35$ & 56 & 90,3 & 77 & 77,0 & 4,62 & $0,03^{*}$ \\
\hline$>35$ & 6 & 9,7 & 23 & 23,0 & & \\
\hline \multicolumn{7}{|l|}{ Pendidikan ibu } \\
\hline Pendidikan dasar & 33 & 53,2 & 39 & 39,0 & 3,13 & $0,07^{*}$ \\
\hline Pendidikan lanjutan & 29 & 46,8 & 61 & 61,0 & & \\
\hline \multicolumn{7}{|l|}{ Pekerjaan ibu } \\
\hline Bekerja & 22 & 35,5 & 36 & 36,0 & 0,00 & 0,947 \\
\hline Tidak bekerja & 40 & 64,5 & 64 & 64,0 & & \\
\hline
\end{tabular}

Keterangan : * Variabel kandidat untuk uji multivariat $(p<0,25$; uji chi-square)

Pada variabel luar, diperoleh data pengetahuan ibu tentang gizi didapatkan dari wawancara ibu balita sebagai responden. Ibu dengan pengetahuan kurang sebanyak $57 \mathrm{ibu}(35,2 \%)$, sedangkan jumlah anggota keluarga $>4$ orang (kategori kurang) berjumlah $94(58,0 \%)$.

\section{Hubungan tingkat pendapatan dengan status gizi balita}

Setelah melakukan analisis univariat, maka dilanjutkan dengan analisis bivariat untuk melihat hubungan variabel bebas dengan variabel terikat pada Tabel 2.

Tabel 2 menunjukkan bahwa tingkat pendapatan mempunyai hubungan yang bermakna dengan status gizi balita dengan nilai $p=0,000$ $(p<0,05)$ dan $R P=4,00$. Hal ini berarti bahwa balita yang mempunyai orang tua dengan tingkat pendapatan kurang memiliki risiko 4 kali lebih besar menderita status gizi kurang dibanding dengan balita yang memiliki orang tua dengan tingkat pendapatan cukup.

\section{Hubungan pola makan dengan status gizi}

Pola makan dengan status gizi balita menunjukkan hubungan yang bermakna dengan nilai $p=0,010(p<0,05)$ dan ratio prevalence $(R P=2,31)$. Hal ini memiliki pengertian bahwa keluarga yang mempunyai pola makan kurang dari tiga kali mempunyai risiko 2,31 kali lebih besar memiliki balita yang mempunyai status gizi kurang dibanding dengan keluarga yang mempunyai pola makan baik ( $\geq 3$ kali/hari) (Tabel 3 ).

\section{Hubungan pengetahuan ibu tentang gizi dengan status gizi}

Pengetahuan ibu tentang gizi dengan status gizi balita tidak menunjukkan hubungan yang bermakna, dapat dilihat dari nilai $p=0,46(p>0,05)$ dan $R P=1,28$. Sebanyak 24 ibu (14,8\%) mempunyai pengetahuan yang kurang dan memiliki balita dengan status gizi kurang, seperti tertera pada Tabel 4.

\section{Hubungan jumlah anggota keluarga dengan status gizi}

Tabel 5 menunjukkan bahwa jumlah anggota keluarga dengan status gizi tidak memiliki hubungan yang bermakna dengan nilai $p$ sebesar 0,33 $(p>0,05)$ dan $R P=0,72$. Sebagian besar keluarga memiliki jumlah anggota $>4$ orang dengan status gizi kurang $(53,2 \%)$. 
Tabel 2. Hubungan tingkat pendapatan dengan status gizi balita

\begin{tabular}{|c|c|c|c|c|c|c|c|c|c|}
\hline \multirow{3}{*}{$\begin{array}{l}\text { Tingkat pendapatan } \\
\text { (Rp) }\end{array}$} & \multicolumn{4}{|c|}{ Kategori status gizi } & \multirow{3}{*}{$C^{2}$} & \multirow{3}{*}{$\mathbf{p}$} & \multirow{3}{*}{ RP } & \multicolumn{2}{|c|}{$95 \% \mathrm{Cl}$} \\
\hline & \multicolumn{2}{|c|}{ Kurang } & \multicolumn{2}{|c|}{ Baik } & & & & & \\
\hline & $\mathbf{n}$ & $\%$ & $\mathbf{n}$ & $\%$ & & & & Min & Maks \\
\hline Kurang (< Rp 232.989,-) & 31 & 19,1 & 20 & 12,4 & 1596 & 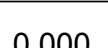 & 400 & 198 & 804 \\
\hline Cukup ( $\geq \operatorname{Rp} 232.989,-)$ & 31 & 19,1 & 80 & 49,4 & 15,96 & 0,000 & 4,00 & 1,98 & 8,04 \\
\hline
\end{tabular}

Tabel 3. Hubungan pola makan dengan status gizi

\begin{tabular}{|c|c|c|c|c|c|c|c|c|c|}
\hline \multirow{3}{*}{ Pola makan } & \multicolumn{4}{|c|}{ Kategori status gizi } & \multirow{3}{*}{$\mathrm{C}^{2}$} & \multirow{3}{*}{$\mathbf{p}$} & \multirow{3}{*}{$\mathbf{R P}$} & \multicolumn{2}{|c|}{$95 \% \mathrm{Cl}$} \\
\hline & \multicolumn{2}{|c|}{ Kurang } & \multicolumn{2}{|c|}{ Baik } & & & & & Maks \\
\hline & $\mathbf{n}$ & $\%$ & $\mathbf{n}$ & $\%$ & & & & IVIIn & IVlaks \\
\hline Kurang (<3 kali/hari) & 37 & 22,8 & 39 & 24,1 & \multirow{2}{*}{6,57} & \multirow{2}{*}{0,010} & \multirow{2}{*}{2,31} & \multirow{2}{*}{1,21} & \multirow{2}{*}{4,42} \\
\hline Baik $\quad(\geq 3$ kali/hari $)$ & 25 & 15,4 & 61 & 37,7 & & & & & \\
\hline
\end{tabular}

Tabel 4. Hubungan pengetahuan ibu tentang gizi dengan status gizi

\begin{tabular}{|c|c|c|c|c|c|c|c|c|c|}
\hline \multirow{3}{*}{ Pengetahuan } & \multicolumn{4}{|c|}{ Kategori status gizi } & \multirow{3}{*}{$\mathrm{C}^{2}$} & \multirow{3}{*}{$\mathbf{p}$} & \multirow{3}{*}{$\mathbf{R P}$} & \multicolumn{2}{|c|}{$95 \% \mathrm{Cl}$} \\
\hline & \multicolumn{2}{|c|}{ Kurang } & \multicolumn{2}{|c|}{ Baik } & & & & & \\
\hline & $n$ & $\%$ & $\mathbf{n}$ & $\%$ & & & & Min & Maks \\
\hline Kurang $(<80)$ & 24 & 14,8 & 33 & 20,3 & \multirow{2}{*}{0,54} & \multirow{2}{*}{0,46} & \multirow{2}{*}{1,28} & \multirow{2}{*}{0,66} & \multirow{2}{*}{2,48} \\
\hline Baik $(\geq 80)$ & 38 & 23,4 & 67 & 41,5 & & & & & \\
\hline
\end{tabular}

Tabel 5. Hubungan jumlah anggota keluarga dengan status gizi

\begin{tabular}{|c|c|c|c|c|c|c|c|c|c|}
\hline \multirow{3}{*}{ Pengetahuan } & \multicolumn{4}{|c|}{ Kategori status gizi } & \multirow{3}{*}{$\mathrm{C}^{2}$} & \multirow{3}{*}{$\mathbf{p}$} & \multirow{3}{*}{$\mathbf{R P}$} & \multicolumn{2}{|c|}{$95 \% \mathrm{Cl}$} \\
\hline & \multicolumn{2}{|c|}{ Kurang } & \multicolumn{2}{|c|}{ Baik } & & & & Min & Maks \\
\hline & $\mathbf{n}$ & $\%$ & $\mathbf{n}$ & $\%$ & & & & IVIII & IVIaks \\
\hline Kurang (>4 orang) & 33 & 53,2 & 61 & 61,0 & 095 & 033 & 072 & 038 & 138 \\
\hline Baik $\quad(\leq 4$ orang) & 29 & 46,8 & 39 & 39,0 & 0,95 & 0,33 & 0,12 & 0,30 & 1,30 \\
\hline
\end{tabular}

\section{Analisis multivariat}

Analisis multivariat dilakukan untuk melihat variabel yang lebih dominan. Dalam penelitian ini, tingkat pendapatan, pola makan, umur ibu dan pendidikan ibu mempunyai hubungan yang bermakna dengan status gizi balita. Sehingga analisis dilanjutkan pada analisis multivariat menggunakan uji multiple logistic regression atau regresi logistik ganda, seperti tertera pada Tabel 6.

Tahapan yang dilakukan pada analisis multivariat untuk mendapatkan model terpilih terbagi dalam 2 step (langkah). Pada step 1, variabel yang dimasukkan adalah tingkat pendapatan, pola makan, pendidikan ibu, dan umur ibu. Variabel yang bermakna dilanjutkan pada step 2 untuk memilih model yang terbaik, yaitu tingkat pendapatan, pendidikan ibu, dan umur ibu.

Tingkat pendapatan dan umur ibu memiliki hubungan yang bermakna $(p<0,25)$ dengan nilai Exp
( $\beta$ ) adalah 4,35 dan 3,48. Variabel yang dominan memiliki hubungan dengan status gizi adalah tingkat pendapatan, artinya balita yang mempunyai orang tua dengan tingkat pendapatan kurang memiliki risiko 4,35 kali lebih besar terkena status gizi kurang dibanding dengan balita yang mempunyai orang tua dengan tingkat pendapatan cukup.

\section{BAHASAN}

Berdasarkan hasil analisis tingkat pendapatan orang tua dengan status gizi balita, memiliki hubungan yang bermakna terlihat dari nilai $p=0,000$ $(p<0,05)$ dengan $R P=4,00$ pada analisa bivariat. Hal ini berarti balita yang mempunyai orang tua dengan tingkat pendapatan kurang memiliki risiko 4 kali lebih besar terkena status gizi kurang dibanding dengan balita yang memiliki orang tua dengan tingkat pendapatan cukup. Penelitian ini sejalan dengan penelitian lain di Kecamatan Mandai 
Tabel 6. Analisis multivariat

\begin{tabular}{|c|c|c|c|c|c|c|}
\hline \multirow{2}{*}{ Variabel } & \multirow{2}{*}{$\beta$} & \multirow{2}{*}{ SE } & \multirow{2}{*}{$\mathbf{p}$} & \multirow{2}{*}{$\operatorname{Exp}(\beta)$} & \multicolumn{2}{|c|}{$95 \% \mathrm{Cl}$} \\
\hline & & & & & Min & Maks \\
\hline Model yang dipilih & & & & & & \\
\hline $\begin{array}{l}\text { Tingkat Pendapatan } \\
\text { Kurang } \\
\text { Cukup (R) }\end{array}$ & 1,47 & 0,37 & $0,000^{*}$ & 4,35 & 2,09 & 9,03 \\
\hline $\begin{array}{l}\text { Umur ibu } \\
\quad \leq 35 \text { tahun } \\
\quad>35 \text { tahun }(\mathrm{R})\end{array}$ & 1,24 & 0,53 & $0,019^{*}$ & 3,48 & 1,23 & 9,86 \\
\hline
\end{tabular}

Keterangan: (R) Kelompok referensi

Kabupaten Maros yang menunjukkan hubungan yang bermakna antara tingkat pendapatan keluarga dengan status gizi balita (9). Penelitian di Afrika menemukan hubungan yang bermakna antara tingkat pendapatan dengan status gizi, prevalensi gizi kurang menurun secara nyata ketika pendapatan meningkat (10). Pada penelitian lainnya juga dibuktikan hubungan yang bermakna antara pendapatan keluarga dengan kejadian gizi buruk (11). Pendapatan keluarga terkait dengan pembelian dan pemilihan bahan makanan. Anak yang tidak cukup makan, daya tahan tubuhnya (imunitas) dapat melemah. Dalam keadaan demikian, anak mudah diserang infeksi, kurang nafsu makan, dan akhirnya rentan terhadap kurang gizi.

Variabel lainnya adalah pola makan dengan status gizi memiliki hubungan yang bermakna dengan nilai $p=0,010(p<0,05)$ dan $R P=2,31$, artinya balita yang mempunyai pola makan kurang dari 3 kali sehari berisiko 2,31 kali menjadi status gizi kurang. Penelitian di Jambi tentang pola makan anak, asupan zat gizi, dan status gizi balita dilihat dari jenisnya $54,2 \%$ sudah berada dalam kategori lengkap dalam pola makan dan jika dilihat dari frekuensi makannya $52,1 \%$ berada dalam kategori baik (12).

Pengetahuan merupakan salah satu domain yang akan mempengaruhi perilaku seseorang (13). Pengetahuan ibu tentang gizi yang merupakan variabel luar pada penelitian ini dengan status gizi balita tidak menunjukkan hubungan yang bermakna dengan nilai $p=0,46(p>0,05)$ dan $R P=1,28$, meskipun jumlah ibu yang memiliki pengetahuan baik lebih banyak $(41,5 \%)$ daripada ibu yang memiliki pengetahuan kurang. Penelitian lain di Indragiri Hilir yang sejalan dengan penelitian ini yang menunjukkan tidak ada perbedaan pengetahuan pada kelompok ibu-ibu yang anaknya tidak mendapatkan pendidikan gizi di sekolah (14). Pengetahuan gizi yang dimiliki mempunyai hubungan positif dalam memilah-milah bahan makanan yang akan diberikan kepada anak (9). Penelitian di Asia Pasifik menjelaskan bahwa pengetahuan gizi merupakan faktor yang cukup penting, namun bukan untuk perubahan perilaku konsumen makanan. Pengetahuan gizi berpengaruh kecil, tetapi penting dalam penerapan kebiasaan makanan sehat. Pengetahuan adalah bagian dari sistem yang terbuka. Konsumen akan menerjemahkan pengetahuan itu dan melakukan hal-hal yang mereka suka (15). Sebaliknya, penelitian lain di Langkat tahun 2005 menunjukkan hubungan yang bermakna antara pengetahuan ibu dengan status gizi balita. Semakin tinggi pengetahuan dan banyaknya pengalaman, semakin bervariasi ibu menyediakan makanan bagi balitanya sehingga kualitas dan kuantitas makanan yang disajikan mempunyai nilai gizi yang tinggi (16).

Pada penelitian ini, jumlah anggota keluarga tidak menunjukkan hubungan yang bermakna dengan nilai $p=0,33(p>0,05)$. Penelitian di wilayah pesisir Jawa Barat tahun 2008 hingga 2009 meneliti bahwa besar keluarga tidak berpengaruh terhadap kesejahteraan keluarga nelayan dengan menggunakan kriteria World Bank, Badan Pusat Statistik (BPS), Badan Koordinasi Keluarga Keluarga Berencana Nasional (BKKBN), dan Bantuan Langsung Tunai (BLT) dengan jumlah anggota keluarga inti (<4). Keluarga dengan jumlah anggota keluarga yang lebih sedikit memiliki peluang untuk lebih sejahtera dibanding dengan 
yang memiliki jumlah anggota keluarga yang lebih besar (17). Penelitian ini sejalan dengan penelitian di Langkat, Sumatera Barat tahun 2001 yang menunjukkan tidak ada perbedaan bermakna antara proporsi balita kurang energi protein (KEP) dengan jumlah anggota keluarga $(p=0,531)(18)$. Berbeda dengan penelitian di Lombok Barat tahun 2007 menunjukkan bahwa jumlah anggota keluarga berpengaruh signifikan terhadap aspek dominan pola asuh. Hal ini berarti semakin kecil jumlah anggota keluarga, ibu mempunyai waktu yang lebih banyak untuk mengasuh anak sehingga tumbuh kembang anak dapat dipantau dan anak terhindar dari status gizi kurang dan buruk (19). Pendidikan merupakan aspek penting dalam menunjang kualitas manusia, seperti tersirat dalam indeks pembangunan manusia (IPM) (20). Penelitian lain di Ghana menyebutkan bahwa pengetahuan gizi ibu secara bebas berhubungan dengan status gizi setelah mengontrol efek dari variabel-variabel lain yang bermakna. Pendidikan ibu di sisi lain tidak ditemukan secara bebas berhubungan dengan status gizi, artinya bahwa pengetahuan praktis ibu tentang gizi lebih penting daripada pendidikan formal ibu untuk status gizi anak (21).

Pada analisis multivariat, variabel yang dimasukkan adalah yang memiliki nilai $p<0,25$. Yang termasuk dalam analisis ini yaitu tingkat pendapatan, pola makan, umur ibu, dan pendidikan ibu, sehingga analisis dilanjutkan pada analisis multivariat menggunakan uji multiple logistic regression atau regresi logistik ganda. Pada analisis multivariat, variabel tingkat pendapatan, pola makan, umur ibu, dan pendidikan ibu bukan merupakan variabel dominan. Penelitian di Tembalang menunjukkan tidak ada hubungan antara umur ibu dengan status gizi balita. Hal ini terjadi karena kemungkinan kelompok umur ibu memiliki pola asuh yang hampir sama dan berasal dari keluarga dengan status sosial ekonomi yang sama (22). Variabel yang paling dominan memiliki hubungan dengan status gizi adalah tingkat pendapatan dengan $\mathrm{RP}=4,35$. Hal ini bahwa balita yang mempunyai orang tua dengan tingkat pendapatan kurang mempunyai risiko 4,35 kali lebih besar terkena status gizi kurang dibanding balita yang memiliki tingkat pendapatan cukup.
Variabel luar lainnya adalah pengetahuan ibu tentang gizi dengan status gizi dan jumlah anggota keluarga dengan status gizi tidak menunjukkan hubungan yang bermakna. Pengetahuan ibu yang rendah berada pada domain kognitif tingkat memahami, aplikasi dan analisis. Faktor penguat yaitu sikap dan perilaku tokoh masyarakat/tokoh agama/tokoh adat dan petugas kesehatan, sehingga dengan melihat contoh menyebabkan pola pikir dan wawasan pengetahuan ibu lebih berkembang.

\section{KESIMPULAN DAN SARAN}

Rata-rata distribusi tingkat pendapatan per kapita keluarga nelayan sebesar Rp 407.700,-Balita yang mempunyai orang tua dengan tingkat pendapatan cukup memiliki status gizi yang lebih baik dibanding dengan balita yang mempunyai orang tua dengan tingkat pendapatan kurang. Balita yang mempunyai pola makan cukup memiliki status gizi yang lebih baik dibanding dengan balita yang mempunyai pola makan kurang.

Untuk meningkatkan pendapatan keluarga, diharapkan kepada Dinas Kesehatan dan Dinas Perikanan dapat memberikan pelatihan melalui teknologi tepat guna sehingga meningkatkan pengetahuan dan keterampilan masyarakat tentang pengolahan, penyimpanan/pengawetan makanan agar tersedia makanan berbahan dasar ikan dan hasil olahannya dalam jumlah cukup dan daya simpan yang lama sehingga dapat menjadi sumber pendapatan.

Untuk meningkatkan pola makan, diharapkan kepada Dinas Kesehatan, Dinas Pemberdayaan Perempuan, Pemerintah Distrik, dan PKK secara rutin dan berkala memberikan penyuluhan berupa komunikasi, informasi, dan edukasi gizi (KIE gizi) agar masyarakat memiliki pemahaman yang benar tentang triguna makanan, jenis, dan frekuensi makan dalam konsep sosio-budaya dan kesehatan.

\section{RUJUKAN}

1. Departemen Kesehatan Repuplik Indonesia. Pedoman umum pemberian makanan pendamping air susu ibu (MP-ASI) lokal. Jakarta: Departemen Kesehatan Rl; 2006. 
2. Departemen Kesehatan Repuplik Indonesia. Data riset kesehatan dasar (Riskesdas) 2010 [Internet]. Jakarta: Balai Penelitian dan Pengembangan Kesehatan RI; 2010. Available from: http://www.litbang.depkes.go.id

3. Jayapura DKK. Pemantauan status gizi. Jayapura: Dinas Kesehatan Kota Jayapura; 2008.

4. Ayomi C, Mampioper. Konsumsi pangan lokal di Papua rendah [Internet]. 2008 [cited 2008 Apr 28]. Available from: $h$ ttp://tabloidjubi.wordpress. com

5. Badan Pusat Statistik Kota Jayapura. Jayapura dalam angka. Jayapura: BPS Kota Jayapura; 2010.

6. Suebu B. Kami menanam, kami menyiram, Tuhanlah yang menumbuhkan. Jayapura: Pemerintah Provinsi Papua, Jayapura; 2007.

7. Nugroho S. Besar sampel dalam penelitian kesehatan. Yogyakarta: Digibooks; 2010.

8. Lemeshow S, Hosmer D, Klar J, Lwanga S. Besar sampel dalam penelitian kesehatan. Yogyakarta: Gadjah Mada University Press; 1997.

9. Khaeriyah. Hubungan tingkat konsumsi energi dan protein dengan status gizi balita di Kelurahan Persiapan Bontoa Kecamatan Mandai Kabupaten Maros. J Med Nusant. 2001;22(4):468-89.

10. Salah E, Mahgoub, Nnyepi M, Teori Theodore B. Factors affecting of malnutrition among children under three years of age in Botswana, African. J Food Agric Nutr Dev. 2006;6(1):1-15.

11. Anwar, K, Juffrie $M$, Julia M. Faktor risiko kejadian gizi buruk di Kabupaten Lombok Timur, Provinsi Nusa Tenggara Barat. J Gizi Klin Indones. 2006;2(3):108-16.

12. Erni, Juffrie M, Rialihanto M. Pola makan, asupan zat gizi, dan status gizi anak balita Suku Anak Dalam di Nyogan Kabupaten Muaro
Jambi Provinsi Jambi. J Gizi Klin Indones. 2008;5(2):84-90.

13. Notoatmodjo $S$. Kesehatan masyarakat ilmu dan seni. Jakarta: Rineka Cipta; 2007.

14. Zulkarnaini, Toto $S$, Untung S. Pengaruh pendidikan gizi pada murid sekolah dasar terhadap peningkatan pengetahuan, sikap, dan perilaku ibu keluarga mandiri sadar gizi di Kabupaten Indragiri Hilir. J Gizi Klin Indones. 2006;3(1):29-33.

15. Worsley A. Nutrition knowledge and food consumption: can nutrition knowledge change food behaviour? Asia Pasific J Clin Nutr. 2002;11:S579-85.

16. Mardiana. Hubungan perilaku gizi ibu dengan status gizi balita di Puskesmas Tanjung Beringin Kecamatan Hinai Kabupaten Langkat 2006. Universitas Sumatera Utara; 2006.

17. Istiqlaliyah M, Hartoyo, Ujang S, Achmad F, Herien P. Kondisi sosial ekonomi dan tingkat kesejahteraan keluarga: kasus di Wilayah Pesisir Jawa Barat. J IIm Kel Konsum. 2010;3(1):1-10.

18. Orisinal. Faktor-faktor yang berhubungan dengan status gizi balita di Sumatera Barat tahun 2001. Universitas Indonesia; 2003.

19. Luh S, Chandradewi. Studi tentang karakteristik keluarga dan pola asuh pada balita gizi kurang dan gizi buruk di Kabupaten Lombok Barat. J Kesehat Prima. 2008;2(2):296-303.

20. Sekretariat Negara RI. Indeks pembangunan manusia Indonesia. Jakarta: Sekretariat Negara RI; 2007.

21. Yaa A, Sturla K. Maternal nutrition knowledge and child nutritional status in the Volta Region Ghana. Matern Child Nutr. 2005;1(2):100-10.

22. Meikawati, W, Hersoelistyorini W. Hubungan karakteristik ibu dan tingkat sosial ekonomi keluarga terhadap kasus gizi buruk pada balita di Kelurahan Tandang Kecamatan Tembalang. J Unimus. 2008;1(1):148-57. 